\title{
The Politics of Assassination in Democratic Nigerian Society: An Appraisal of Ahmed Yerima's Play, The Angel
}

\author{
Reuben Embu*, Samuel O. Igomu \\ Department of Theatre \& Film Arts, University of Jos, Nigeria
}

Copyright $(02016$ by authors, all rights reserved. Authors agree that this article remains permanently open access under the terms of the Creative Commons Attribution License 4.0 International License.

\begin{abstract}
As an effective medium of communication, playwrights use drama as a viable tool for socio-political commentaries. This paper uses Ahmed Yerima's play, The Angel, to critically $\mathrm{x}$-ray the precarious nature of the political climate in Nigeria vis-à-vis the affirmation of the widely held view that in the enterprise of politics, there are neither permanent friends nor enemies but only permanent interests. Against the backdrop of politics, in broad ramifications, being dubbed a 'dirty game,' the paper explores the various degrees of sordid and heinous acts that politicians unscrupulously indulge in to outwit rivals perceived as, somewhat, formidable encumbrances. These include conspiracy, bribery, betrayal, blackmail, kidnap, and at its most political assassination amongst other forms of political violence which are all indices of threat to Nigeria's democracy and national development. The paper concludes that although politics is a sine qua non to political leadership positions in the country, it does not necessarily have to be a do or die affair or a vicious battleground for wanton bloodshed. This, therefore, can be possible and become a reality if and only when political actors truly embrace politics that is premised on ethics and integrity, and having utmost regard for human life and for the people they want to lead.
\end{abstract}

Keywords Politics, Politicians, Political Violence, Political Assassination, Democracy, Nigeria

\section{Introduction}

Political violence, as a socio-political phenomenon, has been for ages and part of human history. Ronald F. White presents a general view of political assassination, as a manifestation of political violence, to be a horrible feature of politics that seems somewhat ubiquitous:

Political assassination is one of the least understood forms of lethal aggression among humans. Despite its alarming frequency and profound influence on the course of human history, historians, psychologists, sociologists, and political scientists have contributed little to our understanding of the general phenomenon. Although the statistics are notoriously difficult to decipher, recent research indicates that worldwide at least 78 heads of state have been assassinated between 1946 and 2000. Since then, that number has increased significantly. However, this number fails to capture the true magnitude of this global phenomenon. During that same era, a staggering number of other leaders have also been targeted, including lower level politicians, political candidates, and cultural leaders. Depending upon one's definition of "assassination" we might also include more recent targets such as leaders of terrorist organizations, criminal witnesses, lawyers, judges, journalists, political adversaries, and even former spies. (1)

In Nigeria and most of the developing world politics, assassination has become an endemic evil attribute and means for people to attain power and material goods. Through the years, political violence has left indelible marks on historical landscape throughout societies in Nigeria and Africa in general. Political violence is characterised by both direct and structural violence used by a state, political party, individual politicians or groups to achieve its objectives. From post-independence through military era to the present day democratic dispensation, political violence has permeated the country. Political violence, in all its sordid and heinous forms, has become part and parcel of political contest across the country. The various forms political violence takes in Nigeria include but not limited to torture, kidnap and death threat, clashes between armed gangs/thugs employed by rival political gladiators, and assassination. In affirmation, Aver, Nnorom and Targba stresses that "political violence manifest in acrimony, assault, assassination, intimidation, harassment, maiming and killing consequently these affect the existing social relationship in the society" (266). Political violence is an atrocious detrimental socio-political disease that has plagued the Nigerian democratic state because many politicians, 
unfortunately, embrace it as an indispensible offensive and/or defensive mechanism and as a necessary part of political tussles. It is evilly an appalling act that leads to the destruction of human lives and properties. In this regard, Aver, Nnorom and Targba advance their commentary on political violence within the purview of political assassination thus:

In Nigeria, political violence has become highly disruptive to social life, thereby causing divisions in families and communities as well as causing antagonisms among and within social groups. Nigerians have witnessed several cases of political violence in the form of assassinations, bomb-blasts, intimidations, murders, and destruction of properties in time past and now on the increase. The effect of this menace in Nigeria is tending in some respects towards social disaggregation into its constituent ethnic and sub ethnic groups divisions... The current surge of political violence is a very disturbing trend towards social progress and prosperity. In fact, the political violence is creating difficult living standards for Nigerians. (264)

These vicious practices are not healthy for any country and especially Nigeria where democracy is still being nurtured. Political assassination and all other forms of political violence are all elements that have contributed to the decay and rot in Nigeria and its political sphere. This ugly state of the nation has and will continue to spur artists playwrights and musicians alike - who, over the ages, use art to make constructive social commentaries on the happenings in the society in order to affect some positive changes in man and his environment. Eedris Abdulkreem, one of Nigeria's musical socio-political commentators, bluntly captured and re-echoed the calamitous prevalence of political assassination in his controversial 2004 song titled Jaga Jaga. An excerpt of the song goes thus:

Nigeria Jaga Jaga
Everything scather scather
Poor man dey suffer suffer
Gbosa, gbosa, gun shot inna di air
Armed robber came to your house
Eno thief money, eno rape your wife
Went straight up to your bedside (Gbosa)
Six feet now you are down
Which armed robber no wan money
Which armed robber no wan jolly
Na political armed robber be that
Na wetin dey kill Nigeria o

Political assassination is more often than not easily influenced by rivalry on the grounds of incompatibility of political motives and interests among political parties and politicians. Bolstering this viewpoint, Thomas Hobbes rightly avers in his seminal work Leviathan (1996): "And therefore if any two men desire the same thing, which nevertheless they cannot both enjoy, they become enemies; and in the way to their end, (which is principally their own conservation, and sometimes their delectation only), endeavour to destroy, or subdue each other" (83). On this parlance, scholars like Galtung (1969), Apter (1997), Huntington (1997), Kleinman (2000), Kapfere (1997), Travis (2000), Spencers (2007) amongst others have all shared common grounds and written on the interconnectedness of power, politics and violence.

In the Medieval times, the term murder was used to describe the slaying of prominent Christians by the Hashshashin, a secret Islamic sect. In the $21^{\text {st }}$ century, however, assassination substituted murder to describe killings committed for political reasons. "Assassination - the politically motivated killing of high-profile individuals - has always been part of man's struggle for power, from the removal of tyrants in classical civilizations to the state-sanctioned 'decapitation strikes' of the present day" (Porter 11).

Today, the tragedy of political violence vis-à-vis political assassination has engulfed wider sections of our society where politics, as a bedlam, has become more based on force rather than democratic norms and values. It is against this backdrop that this paper engages in a critical study of this detrimental and devastating venture by politicians, using Ahmed Yerima's play, The Angel, as a paradigm.

\section{Background of Study}

There has been extensive and disturbing history of politically motivated killings over the years in different parts of Africa. Painfully so, "African independence, thus far, has been a record of tragedies. Tragedies in which the African leadership has played a delirious part. Political repression, assassinations and coups, and the pauperisation of the masses" (Onoge 32). To set the right tone and platform for a sagacious discourse on the subject matter of political assassination, it therefore becomes necessary to draw attention to a handful of high-profile killings recorded over the years in some of these African countries, Nigeria inclusive.

One of the most talked about political assassination of the $20^{\text {th }}$ century was the killing of the hero of Congolese independence, Patrice Lumumba. As the first legally elected Prime Minister of the Democratic Republic of Congo (DRC), Patrice Lumumba was assassinated on the $17^{\text {th }}$ of January, 1961 , less than seven months after independence (on the $30^{\text {th }}$ of June, 1960). Apparently, Lumumba was killed for political reasons which, according to various reports, both the US and Belgium were complicit in his murder.

As reported by the BBC in 2013, upon election as Prime Minister, Lumumba was confronted with a breakdown of order - revolt from secessionist groups from the mineral-rich province of Katanga. To quickly restore order and security, Lumumba turned to the Soviet Union for aid. This fateful move triggered panic in London and Washington who all feared the Soviets would get a foothold in Africa much as 
they had done in Cuba, and so the 'doctrine of necessity' became the last resort.

Another political assassination that deserves mention is that of Tunisian politician, Mohamed Brahmi, founder of the Movement of the People Party. Until his assassination on July $25^{\text {th }} 2013$, Brahmi was a member of parliament and also led the opposition Nationalist Movement of the People Party, which is part of the same coalition as Chokri Belaid, another prominent politician assassinated in February $6^{\text {th }}$ of same year. The BBC on the same day Brahmi was killed, quoting Movement of the People Party officials, reported that gunmen on a motor bike shot $\mathrm{Mr}$ Brahmi in his car outside his home in Ariana, Tunis, in front of his wife and daughter. Corroborating this report, local media across the country reported the assailants fired eleven bullets at the politician. All fingers, swiftly, pointed to the governing Islamist Ennahda Party. The murder of Brahmi subsequently sparked mass protests against the Islamist-led government in the capital and other major parts of the country especially the southern town of Sidi Bouzid, the cradle of the Tunisian revolution (Reuters 25 July 2013).

One horrific death in Nigeria that brought the terror of political assassination to limelight in the country is the murder of renowned crusading journalist and founding editor of the Newswatch magazine, Dele Giwa. He was killed by a mail (parcel) bomb in his Lagos home on the $19^{\text {th }}$ of October, 1986. Two days prior to his murder, Dele Giwa had been preposterously accused by a senior official of the Directorate of Military Intelligence of illegally importing and stockpiling arms and ammunition to be used in staging socialist revolution in Nigeria. Alarmed at the charge, Giwa swiftly took necessary step by informing his attorney (Gani Fawehinmi) to follow up the case but the following day he got a call from a security chief (Col. Halilu Akilu) who reassured him that the accusation had stemmed from a misunderstanding. Giwa was made to believe that the issue had been cleared and was intimated on the parcel coming to him from the then C-in-C - Ibrahim Badamosi Babangida.

On the fateful day of his death, as reported in The Nation newspaper in 2011, the parcel which bore the seal of the presidency and had the inscription "To be opened by addressee only," was received by his son Billy and passed on to the father who was seated at the dining table, in company of the London correspondent of Newswatch, Kayode Soyinka. Taking the parcel, he said "this must be from the presidency." He opened it while it lay on his laps and the package exploded, pulverising his pelvis and setting a section of the house on fire. Dele Giwa was being rushed to a nearby hospital when he died. However, miraculously though, Giwa's wife and baby daughter, and kayode Soyinka survived the blast.

In Nigeria still, on June $4^{\text {th }}$, 1996, Alhaja Kudirat Abiola, the articulate wife of the acclaimed winner of the Presidential election held on (the now iconic) June $12^{\text {th }}, 1993$, Chief MKO Abiola, was gruesomely murdered along Lagos-Ibadan express road. At the time of Mrs Abiola's assassination, her husband was in detention (charged with false publication) having been detained by former Head of State, the late Gen. Sani Abacha's military regime for proclaiming himself winner of the 1993 presidential election. Some high-profile persons were held and tried but later acquitted.

On December $23^{\text {rd }}, 2001$, Minister of Justice and Attorney General of the Federation, chief Bola Ige was dastardly murdered inside his bedroom at Ibadan, Oyo State. As usual, in a face-saving show by the police, several persons were fingered in his murder especially the People's Democratic Party (PDP), which Nobel Laureate and literary icon, Wole Soyinka referred to as a "nest of killers." The Guardian Newspaper of $2^{\text {nd }}$ August 2003 quoted Soyinka in a press conference in Lagos as reiterating "I repeat indeed, insist that there is a nest of killers within the PDP... it is evident that the vipers in the nest do not strike only outwards but inwards." The murder case of Ige was muddled up and trial of suspects took several twist and turns as several judges stepped down from the case. Corroborated reports by several news agencies has it that one political thug by the name Fryo, on confession to being part of the murder, implicated the then Deputy Governor of Ige's home state, Osun. He was later left off the hook when the case was withdrawn from the court in 2014 by the Oyo State Government for what it called "want of evidence." Pathetically, Ige's wife died after one of the futile hearings to bring the killers of her beloved husband to justice. Over fourteen years after, the assassination of Chief Bola Ige still remains shrouded in enigma and his killers remain unknown.

Against the backdrop of these and many more individuals and breed of politicians across Africa and particularly in Nigeria that have been brutally murdered, one of Africa's finest writers, Wole Soyinka, in his first Interventions series laments:

We are a nation that kills our best. Generosity is a tainted word. Largeness of heart is regarded as a medical condition, like an enlarged heart, requiring drastic intervention. Tolerance is ridiculed as the mark of weakness. And so we kill the generous, the large of heart, the tolerant. Even the symbols that should heal and bind the nation together are turned into agencies of death - including those of faith, piety, religion. (9)

Soyinka's statement above is an apt insinuation that where, for instance in countries of other continents especially in some developed nations, a cultured politician is revered and considered an asset to the country, in Nigeria like some other African countries, these brand of honourable (in the real and pure sense of the word) individuals cum politicians are seen as threats to the status quo that must be eliminated at all cost. In Interventions II: We, the People...! - being the second series-, Soyinka further comments on the culture of political killings which has eaten deep into the fabrics of Nigeria's political landscape thus:

Alas, such is the nature of their deaths, being political deaths, that they mostly will not die quick and still, but 
will ensure that their death throes, if that is what it takes, bring down the roof around the ears of the living. The desperation of such usurpers of our political will is of a kind to which we are accustomed, one that has produced monstrosities in the form of military dictatorships and the descent of communities, regions and indeed the nation into a lingering state of insecurity, with its attendant ills, not least of which is economic retrogression. (75)

The adverse impact of political assassination, as a type of political violence, on a nation's socio-political structure is devastating. As pointed out by Arie Perliger in The Rationale of Political Assassinations, "political assassination seems to intensify prospects of a state's fragmentation and undermine its democratic nature. The latter is usually manifested in a decline in political participation and a disproportional increase in the strength of the executive branch" (6-7). Throughout human history, there has been the proliferation of both high and low profile political killings as a threat to humanity and that which stirs up feelings of discomfort and uneasiness in citizens. In Africa and Nigeria to be precise, the situation is extremely disturbing and frightening. Lamenting the spate of assassinations that spreads across the country's six geo-political zones, Edwin Madunagu, as quoted by Adeola Durotoye, declares:

Of all the political developments that currently bother me, the one most difficult for me to analyze and comprehend appears to be the new regime of political assassination in the south-east zone of Nigeria. General Sani Abacha's junta first professionalized political assassination, and then developed it into a systematic method of fighting the "enemies" of the state in general and the supporters of Chief Moshood Abiola in particular. After the death of the general and the inauguration of Obasanjo's government, the nation enjoyed a brief assassination-free period. Then the evil regime returned - thus confirming the thesis that a political weapon, once it emerges out of historical circumstances, does not simply disappear, and is not withdrawn at will... I can, without being cynical, advise a Nigerian politician who is scared by the spectre of political assassination to disengage publicly from politics, and be seen to have done so... Whereas before Olusegun Obasanjo became president, the struggle was not altogether a do-or-die affair, it has now become so. (236)

Similarly, just before the 2007general elections in the country, the same concern had been expressed by the then Inspector General of the Nigerian Police, Sunday Ehindero, when he notified the National Assembly of the intensifying trend of political violence:

It is a truism that election plays an important role in our democracy; in fact, without election, there cannot be democracy. However, elections since the 1960s have had their own problems of violence and acrimony. As we approach the 2007 elections, there appears to be a spate of political violence. Politics is about competition for power and of all the criteria of development, be it social, economic or cultural; it is the political criterion that takes the lead particularly in our own system. This is because the stakes are high. That is why all methods are used to achieve political power, including violence. There ought to be a fundamental moral base in politics and the Machiavellian principle of the ends justify the means may not be acceptable. (Durotoye 235-236)

Political assassination has remained, from time past, one of the main outcomes and facets of political violence which politicians utilise in not only settling scores with opponents but also as a political recipe to aid them in their attainment or retention of political offices regardless of the fact that such killing violates the fundamental human rights of the victims. Perhaps, Niccolo Machiavelli's thesis in his book The Prince may have, consciously or unconsciously, influenced the behaviour of these notorious politicians who will do everything humanly possible to achieve their disreputable political goals. Like Machiavelli postulates and as the actions of this political snipers and schemers exemplifies, the end (unacceptably) justifies the means. What this means is that it does not matter whatever strategy or approach right or wrong, lawful or unlawful - political aspirants employ to win elections, attain or maintain political positions or power, what counts is that at the end of the day they are in positions of power. And once they are in power, the means to that power they wield or the position they occupy becomes shrouded in oblivion, negligence, insignificance and never investigated.

However, on a heart-breaking note, the democratic system of a society like Nigeria stands the risk of been crippled so long as the country continues to be riddled and afflicted by the socio-political malaise identified to be political assassination. Given the prevalence of this malaise, the country's democracy and theatre of politics is in a serious quagmire because, as Igbafe and Offiong clearly expresses, "no country in the world can thrive in an atmosphere that is riddled with tension, apprehension, brutality, serial or targeted killings and assassinations. Nigeria, a nation that is yet to attain the status of a developed state can neither survive nor grow in such brutality ridden environment." (016)

\section{Theoretical Framework}

This discourse is anchored on the realist theory of conflict which originates from classical political theory. The theory shares both theological and biological doctrines, and traces the roots of conflict (i.e. political assassination) to an apparent weakness and flaw in human nature which is seen to be selfish and involving desperation in the pursuit of individualised interest defined as power. 
Hans J. Morgenthau explains that inherent forces in human nature are responsible for conflict which he regarded as an imperfection in the world. For him and other realists after him like Kenneth Waltz (2001), they attest to a flawed humanity and man's inherent evil. Morgenthau sees human nature as selfish, individualistic and naturally conflictive and so the likelihood to always pursue personal interests under the cloak of public interests which will inevitably clash with the interest of others and, thus, leads to conflict (4). Morgenthau, cited in Hensel, argues further that "all political phenomena can be reduced to one of three basic types. A political policy seeks either to keep power, to increase power, or to demonstrate power" (4). This makes politics and the quest for political offices a dangerous enterprise and a deadly terrain where only the strong survives and winner takes it all - survival of the deadliest. This politics of bloodshed has been described by John Mearcheimer as "a ruthless and dangerous business" where the great powers "fear each other and always compete with each other for power," with each seeking to maximize its own power relative to its rivals' -- and ultimately seeking to become the system's hegemon (Hensel 4).

The clash of interest and/or values between political players, "the tension between what is and what some groups feel ought to be, the conflict between vested interests and new strata and groups demanding their share of power, wealth and status" (Coser 197) often leads to political violence vis-à-vis assassination. The selfishness and desperation of these politicians to cling to power has been identified by the realist theory of conflict as the reason why political assassinations persist today. And for a country like Nigeria which no longer has to cope with the whips of colonialism although it still must grapple with the reality of an internal conflict and quest for domination and another form of colonization by political parties, power remains a critical subject to identify as a major factor. In this sense, as observed by Soyinka, there is bound to be for politicians, political parties and other political institutions within the quasi-state or the actual state a tragic manifestation of the social operations of power along the parlance of political violence and assassination (Soyinka, Interventions $V$ 29). From the exposition above, there is clearly a relationship between politics, power and conflict in the sense that the essence of politics is to attain political power through a conflicting process (that should and must not necessarily be violent/lethal) given that others are interested and will struggle to get hold of the same power.

Political assassination like other forms of political violence is an avoidable despicable corollary of complex ideological interplay/conflict and lust/hunt for power by ruthless contesting politicians who are unethically bigoted to have little or no regard for human life. These misguided and depraved political actors resort to assassination or elimination of opponents to increase their chances of gaining a desired political position as well as power. Relatedly, Gerhard Falk categorises assassinations for power which are tools in a political power struggle as one of the dimensions to politically motivated killings. The others he identifies to be aristocratic assassination - which targets mainly the elites; assassination based on personal motives or convictions this is often as a result of personal hostility aggravated by past relations or grivieances; religious assassination rationalised by using interpretations of religious texts; nationalism motivated assassination - directed at those perceived and recognised to be unpatriotic; diplomatic assassination - aimed at foreign nationals or figures ( Perliger 22).

According to Kegley and Wittkopf, this theoretical paradigm is "based on the premise that world politics is essentially and unchangeably a struggle among self-interested states for power and position under anarchy, with each competing state pursuing its own national interests" (31). By implication thus, it is a struggle among individuals (politicians) for power and positions of authority. The founding father of the realist theory of conflict is the Greek historian Thucydides who wrote the seminal account of the war between Athens and Sparta. The core of this theory is that people are by nature narrowly selfish and ethically flawed and, so, would exude insatiable lust for power that they would strive to gratify against all odds.

\section{Synopsis of the Play, The Angel}

The play opens at Otunba's house. Otunba prays to God over the condition of his wife, Rachael, who is stricken with a kidney disease for about two years. He asks God to take away his life instead of his dear wife. Otunba stops the prayer and switches on the radio only to be greeted with the announcement on the death of another prominent politician who is alleged to have died in a car crash. Rachael starts coughing violently and Otunba reaches for the phone which he uses in calling Tela, their doctor and a cousin to Rachael. Tela arrives some few minutes later and administers some drugs to Rachael. Otunba tells him that he believes in miracles and as such, Rachael would be healed of her ailment. Tela, however, advises him to inform his daughters in London of their mother's ill health so they could send over some money for her drugs. Otunba does not budge, insisting that he and his wife have decided to keep the children out of it and not burden them with additional responsibility. He further reveals that his wife became sick after the death of their only son, Christopher, in a car crash. It is his belief that Christopher's death has had a big impact on his wife because, amongst his three children, Christopher was her favourite.

Otunba suddenly informs Tela to take Rachael's life, giving her an injection to that effect but he refuses, dissuading Otunba from hatching such evil thought. As Tela takes his leave, he promises to send someone over with food for him to eat. Otunba thanks Tela and also promises to call him should the need arises. Subsequently, Otunba dashes over to Rachael who, at the moment, screams from her sleep where she sees Christopher in a dream. She narrates the dream to Otunba who, in turn, uses the opportunity to 
apologise to her. Otunba is overwhelmed with feelings of guilt for causing Rachael so much pain as a Chairman of the Local Government, and also soiling their marriage by getting Bimbo, Rachael's friend, pregnant; albeit she and the child died during childbirth. Otunba asks for Rachael's forgiveness.

Rachael falls asleep. Chief, a prominent politician who was killed a week ago, appears in the house. Otunba has the power to see Chief even though a ghost and Chief, too, is surprised that Otunba can see him clearly. However, Otunba regards Chief as an angel who has the power to heal his wife, and tells him of how his son died in an accident and how his family, as a result, never remained the same again ever since. Chief also pleads with him to, on his behest, get in touch with his wife over the phone and have her come to the house. Otunba obliges.

Chief's wife, Patricia, arrives at Otunba's house in company of Chief's sister by name Jope. At first, both women doubted the genuineness and reality of having Chief - a dead man - present at Otunba's house. Otunba convinces them to believe in their heart that Chief is there, and in doing so, Chief is able to communicate with them. He reveals to them that he was strangled by his brother whom they never suspected, and informs them where he had kept the will in a brief case. The women leave relieved and Otunba falls asleep. He wakes up later to see his wife Rachael hale and hearty, coming out from the kitchen and setting the table. Rachael tells Otunba that she feels strong and that it appears she has seen an angel.

\section{Democracy and Political Intrigues in The Angel}

Democracy describes a type of political system in a (democratic) country where all eligible citizens have the right to vie for elective positions, participate, either directly or indirectly, in the decision-making process that would affect them. According to Robert Dahl (1998), democracy is a system that allows meaningful competition for positions of government power, an inclusive level of political participation in the selection of leaders, control of the agenda for citizens, opportunities for enlightened understanding, freedom of expression and fairly conducted elections. Joseph Schumpeter, cited in John Medearis, buttressing this point, describes democracy as a "free competition for a free vote" (271). Deducible from these conception of democracy are that eligible and qualified citizens can compete for positions without fear or favour, that adult citizens have a right (franchise) to vote, and then, the presence of free and fair elections that are competitive. Therefore, the effectiveness of a true democracy as a dynamic means of governance is measured by the degree of citizen's involvement in the political process of electioneering either as an aspirant or an electorate.

In Nigeria like most other African countries, it is a representative democracy where citizens usually elect persons to represent them at the different tiers of government Local, State and Federal. Nigeria prides itself today as a democratic nation yet the incessant vice of political killings is one major problem that results from a society that is not a democracy. Lamenting this dark reality, the late legal icon Gani Fawemi cited in Ajani (2001) articulates that what we have been witnessing is not truly democracy but a mindless display of craziness and irrationality by members of the political class, and unless quickly checked, the democratic edifice will surely collapse and we would blame ourselves for the unprecedented flow of blood that will follow (9). Tela, conversing with Otunba, sees this aberration:

Tela: With the world turned upside down, I bet God moved heaven too... This place stinks, and not even God can stand its stench... (16)

Nigeria as a democratic nation is ailing and one of the consequences of this ailment is the cascading standard of social justice in the country where human rights violations, political violence and the declining social standards induced by politicians, political parties, and government holds sway. The foremost outcome of political violence today in the country is obviously political assassination, which The Angel rightly exemplifies. Politicians alike, political parties and individual factions adopt it as a necessary evil for political retribution and to gain political positions of power and rulership. Chief, one of the characters in the play, aptly submits:

Politics is one big game... a gamble... a serious game... the desire to have... to possess, the beauty of the office, the smell of the leathers seats. The fast black fleet of siren cars, the fat bottomed women, the greed, the insatiable lust... the sweet smell of the crispy bank notes... all mingled. (29)

The will to power for personal affluence and aggrandisement leads politicians in a violent way, blinded to their conscience or humanity. Igbafe and Offiong bemoan the evil of political assassination which walks freely the streets of Nigeria without impediment but aided and abetted. This, they attributed to "the ineffectiveness and inefficiency of the national security outfits, particularly the police that have failed to live up to its duties by apprehending the culprits and their collaborators" (12).

The play unequivocally lampoons the dismal and face-saving efforts of security agencies in identifying and bringing culprits of such heinous and gruesome murders to justice. Going by the investigative outcome of previous political assassinations in Nigeria, the police are often quick to attribute such cases to armed robbers or hapless individuals, without thorough investigation and substantiated evidence. The announcement Otunba listens to over the radio says "doctor and political associates in police net." Obviously, it is an indictment of the Nigerian Police Force of their ineptitude and hit-and-miss investigative procedure into various and/or previous cases of political assassinations that have remained, till date, enigmatic. Jope talks to Chief: 
Jope: But the country is burning. The police are close to finding those who have a hand in your case. But one stumbling block is they keep saying that they need to find someone with enough reason and motive to commit the crime. But everybody is on the suspect list including the president. The net has been stretched far and wide (36).

The dilatory response of the police and their unending assurances of bringing culprits to justice but which never materialises are also worrisome. The announcement over the radio further highlights this:

Radio: Police Inspector General promises to unfold the mystery of the accident... His political party suspects the ruling party... This brings to six the deaths of prominent politicians before impending elections (p. 12).

Furthermore, the non-physical dimension the play takes show that in the world of the dead, the dead are always aware of their assassins even when it is unknown and unclear to those in the physical world of the living. The dialogue below attests to that:

Patricia: It has been hell, but for your brother. He has been like a pillar to us all.

$\begin{array}{ll}\text { Chief: } & \text { (Chuckles) More like my killer really. } \\ \text { Jope: } & \text { Your what? } \\ \text { Chief: } & \text { My brother, your pillar, was my killer. } \\ \text { Patricia: } & \text { It can't be. He is so nice. He is so... } \\ \text { Chief: } & \text { Like a rock? } \\ \text { Patricia: } & \text { Yes. (p. 36) }\end{array}$

From the dialogue above, it is a clear indication that perhaps those closely related to the deceased and their families, who often show sympathy and empathy, and brings both financial and mental succour to them might just be the perpetrators but are often the least of suspects. Little wonder the holy book says "and a man's enemies will be those of his own household" (Matthew 10:36). Lending a voice to this revelation, Soyinka emphatically submits in his first Interventions series that,

The murderers are among us. Let no one be in any doubt - they sit among us, right within this somber gathering that honours the passage of a hero. There exist also the unwitting collaborators whose blind politics brought this moment to be, whose primitive notions of contestation offered up this lamb on the sacrificial platter. (3)

Some parallels can be drawn between Jesus (Matthew 26:15) and Chief. The former was betrayed by one of his disciples - Judas Iscariot - to be killed; Chief was also betrayed by one of his own - brother - though killed by him as well. Judas sold his master for thirty pieces of Silver/shekels; Chief was sold by his brother for two million naira. It is all about the money and greed lies at the heart of it all. "For the love of money", the Bible says, "is the root of all kinds of evil" (1 Timothy 6:10). Chief reveals this truth to both Patricia and Jope:

Chief: Sit down both of you. (Dumbfounded, both women sit) I could not get a re-nomination form from the party because my brother had joined my political enemies and sold me out for two million naira. The Governor had thought I was to run for Governor, so he bought every living thing around me, including my brother (36).

The winner takes all tendencies in our elections increases the desperation by politicians to go all out and exterminate opponents such that they hire the services of professional assassins to carry out the dirty job. Igbinovia, citing Akamere, notes that these assassinations take various forms such as the use of 'professional assassins,' food poison, and calculated or planned or arranged accidents i.e. plane or car crash (30). Chief's murder was also planned and carefully calculated just like some of the assassinations witnessed in the country in time past.

Chief: That was how he did it. He paid my old driver off. And gave me his man. On the day I was killed, I left the house for a meeting... I never got there. By the gate my brother was there and we picked him up. Halfway to the meeting he strangled me with my tie (38).

Like the Governor and Chief's brother, the politician who hires the services of an assassin and the assassin who does the killing are both callous and unconcerned about the value and sanctity of human life. In carrying out this dastardly act, there should be no trail and so the tracks must be cleaned. A cover up - some sort of alibi - becomes a matter of necessity:

Jope: What about the accident?
Chief: He arranged that after he killed me. It was all
a cover up. Jope: And the autopsy, too? Oh my God, what is this world turning to? The end time is near I tell you, brother killing brother. It is the end time for sure.

Otunba: It is Cain and Abel all over again, if you ask me (38).

This cover up strategy is further observed and exposed by Tor Iorapuu in the play, April 1421, through the character of Youth Leader II: "That is their strategy: clean the tracks. Send a letter bomb; set your house on fire or quarantine you because you are a virus likely to threaten the operating system..." (34).

Political violence, Igbinovia further says, which is epitomised by assassination has become a feature of Nigerian politics since the eras of irrepressible mayhem in Western Nigeria during the first republic (1963) to the later-day form of warring political brigades. Besides the use of illegally held guns to terrorise innocent citizens, quite a number of these armed groups and their collaborators are prepared to settle 'political scores' with immediate effect (30). 
Political violence which is a rampant phenomenon around the world differs from general violence given its specific political goal which is to achieve power and position. In particular, political assassination which has become a way for unscrupulous and selfish politicians to achieve these goals is seen to be an indispensable part of politics. Chief's point of view alludes to this:

Chief: Violence from politics. Can one separate it? No. it is like separating rigging from elections. Life from death. Man from woman. Unless of course, there is an attempt at a reversal of morality. It is the brother to politics... I say can one separate it? Hum? (29)

There is dire need for morality to be brought back from the abyss of perversion where what is right and good has been made wrong and bad, and vice versa. The circle of political assassinations in the country is not a strange development. The list of (unresolved) politically motivated killings has swelled, and is non-exhaustive:

- A member of the Osun State House of Assembly, Mr Odunayo Olagbaju, was on December 19, 2001 brutally murdered in front of a police station in Ile-Ife, Osun State.

- The State Chairman of PDP in Kwara State, Ahmed Pategi, was assassinated on August 15, 2002.

- Lagos State PDP Gubernatorial aspirant, Dele Arojo, was killed by unknown assassins on November 25, 2002.

- On February 18, 2003, an assassination attempt on Chief Paul Unongo failed but a security man in his residence was killed. Chief Unongo was then the ANPP gubernatorial candidate in Benue State.

- On April 19, 2003, Onyewuchi Iwuchukwu, a stalwart of the All Nigerian Peoples Party (ANPP), was killed in Ikeduru Local Council, Imo State.

- Mr Ikenna Ibor, an ANPP councillorship candidate in Anambra State, was assassinated on March 27, 2003.

- Dr Harry Marshal of the ANPP was murdered in his bedroom in Abuja on March 5, 2003. Dr Marshal defected from PDP to ANPP following a rift with some top players of the party and was the National Vice-Chairman of the ANPP (South-south) before he was killed.

- On March 4, 2004, Mr Luke Shingaba, a chairmanship candidate, was killed in his house in Bassa Local Council in Kogi State.

- On March 3, 2004, the convoy of the then Governor of Benue State, George Akume, was assaulted by suspected assassins on his way to Kaduna. Albeit, the Governor survived the attack, a member of PDP's board of trustees, Andrew Agom and Joseph Ngama, a police sergeant were killed.

- On 6 February 2004, PDP National Vice-chairman (South), Chief Aminosoari Dikibo was assassinated in Delta State on his way to the south-south PDP meeting in Asaba.

- In August 2005, a Councillor in Oredo Local Government Council of Edo State, Mr Felix Eboigbe, was murdered.

- PDP's Assistant National Director, Research and Planning, Mr Anthony Ozioko, was on July 27, 2005 murdered in his residence in Saburi-Gwagwa, Abuja.

- On the $30^{\text {th }}$ of June, 2006, a gubernatorial aspirant of the Advanced Congress of Democrats (ACD), $\mathrm{Mr}$ Jesse Aruku, was abducted and killed near his house in Bassa Local council in Plateau State.

- Engineer Funsho Williams, PDP gubernatorial aspirant in Lagos State and Chairman, Board of Directors of Nigeria Maritime Authority (NMA) was murdered in his bedroom after a political meeting on July 27, 2006.

- On August 14, 2006, Dr Ayo Daramola, a PDP gubernatorial aspirant in Ekiti State was murdered in his bedroom at his hometown, Ijan Ekiti.

- On February 7, 2003, Mr Ogbonnaya Uche, a chieftain of the ANPP and a senatorial aspirant in the Orlu senatorial zone, Imo State, was shot dead in his residence not long after he switched party from the PDP to the ANPP.

- In February 2003, Theodore Agwatu, Principal Secretary to the Imo State Governor, was murdered by suspected hired assassins in Owerri.

- On December 25, 2005, Christmas day, the Chairman of Warri South Local Council was murdered.

The list above, which is by no means anywhere near exhaustive or comprehensive, is a reflection and pointer that political assassinations are widespread in Nigeria particularly since the return to democratic rule in 1999. These killings have continued to raise dust in the country and there is somewhat no uncertainty that they have political undertone given that most of the victims of such murders are high-profile politicians.

As the days and years elapses, there continues to be an upsurge in the inventory of politically motivated killings in their various straightforward and complicated forms. In recent times, following the 2015 general elections in Nigeria, the Resident Commissioner for the Independent National Electoral Commission (INEC), in Kano, Mikaila Abdulahi, died in a very bizarre and enigmatic fashion. Mikaila, who oversaw the presidential and national assembly elections in the state, died in a mysterious fire incident in his residence, together with his wife and two daughters. Despite any theory there may have been to account for this death, it remains perceptibly shrouded in mystery - whether or not it is political.

Unfortunately in reality, political assassination is fast becoming an inevitable attribute of the political life and construction in Nigeria as with some other countries, most especially in Africa. Again, the stylish Hobbes expounds:

Hereby it is manifest that during the time men live 
without a common power to keep them all in awe, they are in that condition which is called war, and such a war as is of every man against every man... to this war of every man against every man, this also is consequent: that nothing can be unjust. The notion of right and wrong, justice and injustice, have there no place. Where is no common power, there is no law; where no law, no injustice. Force and fraud are in war the two cardinal virtues. (84)

Morality, therefore, needs to be brought back from the abyss of perversion where evil, wrong and bad has been canonised as good and right and where the sanctity for humanity and human life no longer exists. A travesty of morality is in itself evil and so, morality must be restored to its rightful place of true meaning without any iota adulteration. Sooner rather than later, the spate of political assassinations, if not curbed, will conceivably scare citizens and deter them from political participation. Where and when the citizens become too afraid to take part in the politics of a democratic nation, then the existence of such a democracy is called to question. The Nigerian political ambience must not be transmuted into a gruesome human abattoir where reckless political gladiators who covet to rule come what may, slay rivals perceived to be encumbrances to their excessive goal. Rafiu, Owolabi and Najeen staunchly requests that:

Nigerians and lovers of the country's democracy globally should be concerned about the spate of suspected politically motivated killings that have been the hallmark of Nigerian's body politics since the return to democratic rule in 1999 beyond emotional outbursts and impulsive empathies. (1)

In the same vein, Soyinka, in the prose The Man Died: Prison Notes (1972), articulates that "the man dies in all who keep silent in the face of tyranny" (13). Hence, to fold our arms and watch, and take a cavalier attitude to the proliferated barbaric culture of political assassination and not grapple with it is tantamount to compromising and jeopardising our hard won but fledgling democracy.

\section{Conclusion and Recommendations}

The spate of politically motivated killings in Nigeria since independence through the emergence of democracy till date is so mind-boggling because it has eaten deep into the fabrics of the Nigerian society and its political system. The bloody political war, the inter and intra-political party wrangling and conflicts in most parts of the country are a serious threat of extinction to Nigeria's nascent democracy. Worthy of note is the fact that it becomes extremely difficult for a country riddled with brutality, hostility, tension, oppression, apprehension, wanton termination of lives/properties and/or targeted assassination to thrive economically, socially, politically and otherwise. Suffice therefore to re-echo Soyinka's imploration in the face of Nigeria fast transmuting into a battlefield of political killings:

The killers among us must pause, and reflect. The route to the mind is not the path of bullets nor the path of the blade, but the invisible, yet palpable paths of discourse that may be arduous but ultimately guarantee the enlargement of our private and social beings. Let the killings stop and the intercourse of minds begin. Let these killers understand that we do not simply lament this death, we are resolved to extinguish the impulse that lies behind it. We are bound in a common cause to terminate the impulse that takes our best, our brightest. (Interventions I 11)

The ill-wind of political violence blows no one any good as both the perpetrators and victims all get to feel and bear its devastating brunt someway, somehow and sometime. Violence, in the form of assassination and any other, is not a normal element in politics and, therefore, must not be taken for granted. Sadly, the habit of youth formation as thugs and militia of political parties and politicians through the growing trend of violence in the political sphere to attain selfish goals has left quite a number of youths socialised as extremists and fierce in the society in the face of even the slightest less sinister provocations.

The inability of the security and law enforcement agencies to unravel and resolve political killings is also a threat to the democracy and political climate of the country. The absence of judicial repercussion to serve as deterrent to others and to thwart any recidivists' tendencies has given rise to the habit of impunity with regards to politically motivated assassinations.

To stem the high rate of assassinations, crime and murders, the police and security agencies must be well and fully trained on intelligence gathering, information processing, crime control and prevention as well as other sundry matters that will reduce the high rate of crime and killings. Beyond this, because they are often lured and bought over by fraudulent politicians to be used as stooges, there should be a significant increment in the remuneration of the police, security and other law enforcement agents to an encouraging degree in order to thwart even the slimmest chance of them having to trade their oath of uprightness for some enticing sums of money. Also, the security agencies and judiciary must rise up to the challenge of such occasions to salvage Nigeria from becoming a country where anything can happen - political assassination - without culpability.

There should be re-orientation of the political class on the sanctity of life, and consciousness re-awakening that self-centredness is not a mark of true democracy which should, as a matter of fact, serve the interest of the people they wish to represent and lead. As such, selfishness does not, in any way, promote an honourable and ethical politicking, rather it gives room to deprave and unethical political acts. The importance and role of the media in the re-orientation of the political class and entire society cannot be discounted and over-emphasised. This is because, according to Okigbo, “... there is abundant evidence of learning and behavioural 
effects arising from specific communications" (343). Hence, the potency of the media to influence and shape perception is without gainsaying owing to the fact that they tell and fill the mind of the society with what to think about and meditate on. The media must, as a matter of urgency, continually educate and enlighten our politicians on the need to desist from jungle politics of wanton bloodshed in pursuit of political offices. To this end, the mass media should see to it that politicians realise the evil in political violence vis-à-vis political assassination the same way the society was made to see the evil in colonial rule and military dictatorship. To bring about this change, perceptions have to change as philosophically declared by Otunba in the play:

Otunba: Violence never settles anything right apart from injuring our own soul, it injures the best cause. It lingers after the object of hate has disappeared from the scene to plague the lives of those who have employed it against their foes. (29)

\section{REFERENCES}

[1] Abdulkareem, Eedris. “Jaga Jaga.” Jaga Jaga. 2004. Kennis Music. CD. "A Harvest of Political Assassination." The Nigerian Tribune. Editorial, 15 Aug. 2006: 10+. Print.

[2] Ajani, J. “A Political Philosophy Misunderstood.” Daily Vanguard, 25 Dec. 2001: 9. Print.

[3] Akamere, F. Issues and Concepts of Government and Politics in Nigeria. Lagos: Simak Associates, 2001. Print.

[4] Apter, D. "Political Violence in Analytical Perspective." The Legitimization of Violence. Ed. D. Apter. New York: New York University Press, 1997. 1-32. Print.

[5] Aver, Tyavwase T., Kingsley C. Nnorom and Aondowase Targba. "Political Violence and its Effects on Social Development in Nigeria." International Journal of Humanities and Social Science 3.17 (2013): 261-266. Print.

[6] Blum, W. T. Theories of the Political System. Virginia: Brunswick Publishing Company, 1948. Print.

[7] Coser, Lewis A. "Social Conflict and the Theory of Social Change." The British Journal of Sociology 8.3 (1957): 197-207. Print.

[8] Dahl, Robert A. On Democracy. London: Yale University Press, 1998. Print.

[9] Dawodu, C. M. "Political Assassination." This Day Online. Web. 15 July 2015.

[10] Durotoye, Adeolu. "Political Assassination and Nigeria's $4^{\text {th }}$ Republic: 1999-2007." Kuwait Chapter of Arabian Journal of Business and Management Review 3.11 (2014): 235-242. Print.

[11] Hensel, Paul R. "Power Politics and Contentious Issues: Realism, Issue Salience, and Conflict Management.” Annual Meeting of the International Studies Association. Honolulu, Hawaii. 2 Mar 2005. Lecture.
[12] Hobbes, Thomas. Leviathan. Oxford: Oxford University Press, 1996. Print.

[13] Huntington, Samuel P. Political Order in Changing Societies. New Heaven: Yale University Press, 1968. Print.

[14] Igbafe, Afeaye A. and O. J. Offiong. "Political Assassination in Nigeria: An Exploratory study 1986-2005." African Journal of Political Science and International Relations. 1.1 (2007): 9-19. Print.

[15] Igbinovia, Patrick E. "The Criminal in all of us: Whose Ox have we not Taken." University of Benin Inaugural Lecture series 71. 2003. Print.

[16] Ikelegbe, Augustine. Issues and Problems of Nigeria Politics. Benin City: Imprint Services, 2004. Print.

[17] Iorapuu, Tor. April 1421. Lagos: Dat Publishers, 2007. Print.

[18] Kegley, Charles W. and Eugene R. Wittkopf. World Politics: Trend and Transformation. $8^{\text {th }}$ Ed. London: MacMillan Press Ltd., 2001. Print.

[19] Morgenthau, Hans J. Politics among Nations. $7^{\text {th }}$ Ed. New York: McGraw-Hill, 2006. Print.

[20] Nwokocha, John. "Profile of Political Assassination." Sunday Vanguard 8 Feb. 2004: 5. Print.

[21] Okigbo, Charles. "News Flow and Media Effects: Some Perplexing Question." Mass Communication and National Development. Ed. I. E. Nwosu. Enugu: Star Printing and Publishing Co. Ltd, 1990. Print.

[22] Onoge, Omafume F. "The Crisis of Consciousness in Modern African Literature: A Survey (1974)." Marxism and African Literature. Ed. Georg M. Gugelberger. New Jersey: Africa World Press, Inc., 1985. 21-49. Print.

[23] Orode, J. “A Festering Nest of Murders." Tell Magazine 23 Feb. 2004: 16. Print.

[24] Perliger, Arie. Executive Summary. The Rational of Political Assassinations. The Combating Terrorism Centre at West Point, 2015. Print.

[25] Porter, Lindsay. Assassination: A History of Political Murder. New York: Overlook Press, 2010. Print.

[26] Rafiu, Olaopa O., Akinola Owolabi, and Salaam N. Folasayo. "The Nigerian State, Political Assassination and Democratic Consolidation: A Historical Exploration." African Journal of Political Science and International Relations. 3.2 (2009): 156-164. Print.

[27] Schumpeter, Joseph A. Capitalism, Socialism and Democracy. London: Allen and Unwin, 1976. Print.

[28] Soyinka, Wole. Interventions I. Ibadan: Bookcraft Ltd., 2005. Print.

[29] Interventions II. Ibadan: Bookcraft Ltd., 2005. Print.

[30] Interventions IV. In a Lighter Vein. Ibadan: Bookcraft Ltd., 2006. Print.

[31] The Man Died: Prison Notes. New York: Rex Harper \& Row, 1972. Print.

[32] The New King James Bible. Placed by The Gideons International. New York: Thomas Nelson, Inc., 1985. Print.

[33] Waltz, Kenneth. Man, the State and War. New York: Columbia University Press, 2001. Print. 
[34] White, Ronald F. "Assassination Discourse and Political Power: The Death of Alexander Litvinenko." Assassination Research 5.2 (2008): 1-8. Print.
[35] Yerima, Ahmed. The Angel. Ibadan: Kraft Books Ltd., 2004. Print. 